\title{
Accessement of Wind Power Potential in Katsina State from Meteorological Data
}

\author{
M. A. Balarabe ${ }^{1,2}$, K. Abdullah ${ }^{1}$, M. N. M. Nawawi ${ }^{1} \&$ Fuyi Tan $^{1}$ \\ ${ }^{1}$ School of physics, University Sains Malaysia \\ ${ }^{2}$ Hassan Usman Katsina Polytechnic, Katsina \\ Correspondence: M. A. Balarabe, Hassan Usman Katsina Polytechnic, 2052 Katsina, Nigeria. Tel: \\ 234-806-814-7816. E-mail: mukhtarbalarabea@gmail.com \\ Received: August 12, 2014 \\ doi:10.5539/mas.v8n6p53 \\ Accepted: August 23, $2014 \quad$ Online Published: September 4, 2014 \\ URL: http://dx.doi.org/10.5539/mas.v8n6p53
}

\begin{abstract}
For the need to exploit and optimize the use of all available sources of energy in providing available power supply for industrial and economic development of the rural communities. Nigerian government has initiated some programs in 2005 to look into the potentialities of wind as a means for power generation. In order to complement this effort, surface synoptic wind speed observation data (2008-2013) from NOAA-NCDC for Nigeria was used to analyze the wind characteristics of katsina (13.007' N; 07.661' E; Altitude 05060.0 m; Air density $1.18 \mathrm{~kg} / \mathrm{m} 3$ ). A modified form of an empirical relation for calculating wind power density and energy with height was proposed and uses to analyze site wind profile and the efficiency of electricity production for power generation in Katsina. The measurements have been performed for a period of 6years from January to December in order to cover all seasonal variation of the wind condition. The results showed that katsina falls under Class 7 of the International system of wind classification by recording annual values of mean wind speed extrapolated at $50 \mathrm{~m}$ height to be in the range of $3.5-5.5 \mathrm{~m} / \mathrm{s}$, average power density of $160.6 \mathrm{~W} / \mathrm{m}^{2}$ and an average of $29.6 \mathrm{Kwh} / \mathrm{year}$ of energy can be produced for each month of a year respectively, making the site very suitable for wind turbine applications for power generation.
\end{abstract}

Keywords: Katsina, wind energy, wind power, wind speed

\section{Introduction}

The concern over the production of adequate electricity to drive economic developments is a global issue. However increased dependence of the fossil fuel based sources of energy call for an urgent need to develop and generate the needed electricity from environmentally friendly and non-toxic sources (Mahyoub \& Ahmed. 2012; Ajayi, Fagbenle, and Katende 2011). Other reasons may include the need for basic social amenities in the rural areas to solve the problem of rural-urban migration (Bakwa \& Jabil, 2002). Based on that Nigeria's first attempt to evaluate its energy potential was at the energy policy conference held in Jos in August 1978. This conference considered among other things the non-conventional energy sources like solar and wind energy which were recommended for incorporation in to national energy policy (Bakwa \& Jabil, 2002). Therefore this need to adequate optimize the use of all available sources of energy has led to various efforts at measuring and assessing the potentials and viability of generating electricity from renewable energy resources of which wind is a veritable source (Ajayi et al. 2011).

While a variety of definitions might be given to wind speed depending on the area of interest and application. This paper will use the definition suggested by Estherhuyse (1986). Who defined wind as long scale movement of air mass in the atmosphere. This movement of air is created on global heating primarily by differential solar heating of the earth atmosphere. Air in equatorial is heated more strongly than at other latitudes, causing it becomes higher and denser (sirisena etal, Alfa, \& Bakwa 1991). This thermal imbalance in air set up air in motion simply known as wind. Since every object which is in motion possess kinetic energy, certainly there is energy in the wind and it can be captained and converted into useful mechanical energy such as pumping of water from deep wells and boreholes or in to electric energy in the remote areas (sirisena et al., 1991). Harnessing wind as an energy source hard its merits and flows, wind energy source is reproducible, technology required for its harvesting has already been developed, no environmental pollution and no thermal load to the environment (Bakwa \& Jabil, 2002; Mahyoub \& Ahmed, 2012). 
Despite that the role wind (renewable energy) in general can play in meeting the increasing demand for clean electricity (Mahyoub \& Ahmed, 2012), its significance has not yet been fully appreciated by Government of Nigeria. So to enable wind project develop to a better asses, there is need for reliable information about how strongly? From which direction? And how regularly the wind blows at regional levels such as Katsina state. This is because Katsina state actively engaged in dry season farming for cultivation of crops, sugarcane, vegetables etc. large number of dry season farmers draw water manually from well, some use generators that produce pollutant and may affect crop yield. Therefore increase yield may be recorded if wind mills would be used as an alternative source of energy which is purer and cheaper to oppose the previous method adopted.

Quit a lot of work has been done on wind energy in the industrialized countries then in the less industrialized countries (Sambo et al, 1990) many of which have an abundant supply of wind energy. For instance (katoulis, 1992; Hennessy 1977; Fagbenle and Karayiannis, 1994; ECN-UNDP, 2005; Asiegbu and Iwuoha, 2007; Fadare, 2008; Ajayi, 2009; Ogbonnaya et al. 2009; Fadare, 2010; Fagbenle et al. 2011). Most this author's focus on a weibull distribution to determine the potentialities of local site for wind power /electricity generation since it gives a good fit to experimemtal data (Ajayi et al., 2011)

According to ECN-UNDP (2005) due to varying topography and roughness of Nigeria, large differences in wind distribution within the same locality exist (Ajayi et al. 2011). This is corroborated by the fact that wind resources are site specific and despite reports summarizing for the country, a site-by-site assessment is necessary in order to have proper wind classification for the nation. This work is therefore used to focus on the wind resource assessment study of a wind measuring site in Katsina towns. It assessed the wind energy resources of the sites to determine the magnitude of monthly, yearly and seasonal wind power potentials at meter 50meter height in Katsina state that can possibly be generated from a site based on the historical results for electricity generation.

\subsection{Characteristics of Wind Site}

In accordance with sirisena et al. (1991) the most important measure of a site potential for wind power is annual wind speed, for example sites with mean wind speed less than $3 \mathrm{~m} / \mathrm{s}$ are not often good site for construction of wind mills. Those with the mean between (3-4) $\mathrm{m} / \mathrm{s}$ may be feasible depending on the application modalities and the comparative cost of the other forms of energy. The site with the mean wind speed in the range (5-6) $\mathrm{m} / \mathrm{s}$ or higher can be classified as an excellent area for wind power development. Wind speed is normally zero at ground level and increase steadily with height (Nickovic \& Petkovic, 1987).

\section{Data and Methodology}

The monthly mean wind speed data for Katsina for a period of 6years from (2008-2013) was obtained from NOAA-NCDC to analyze the average monthly, and annual wind speed, available and extractable power in and from the wind as well as to determine the monthly and annual energy of the wind for various wind speed range in the state at $10 \mathrm{~m}$ and $50 \mathrm{~m}$ height.

The measured speed at $10 \mathrm{~m}$ height were extrapolated to 50m height using Nellman's exponential law (Maxwell \& Crokmak, 1984) as

$$
\mathrm{V}_{2}=\mathrm{V}_{1} \quad\left(\frac{z}{10}\right) \mathbf{b}
$$

where $V_{1}$ is the measured wind speed at $10 \mathrm{~m}$ height, $V_{2}$ is the extrapolated wind speed at height $Z=50 \mathrm{~m}$ in this case, the value of roughness factor $b$ varies from less than 0.1 over the top of the steep hills to over 0.25 in the sheltered location (Ahmed, 2010) or estimated from the relation

$$
\alpha_{L n \frac{V 1 / v 2}{h 2 / h 1}}
$$

For this study ${ }_{b}$ is assumed to be 0.2 considering Katsina as a forested region. The power available in the wind is given by Pwind $=1 / 2 \rho A V 3(\mathrm{w} / \mathrm{m} 2)$

where $\rho$ is standard air density $\left(\rho=1.225 \mathrm{kgm}^{-3}\right.$ dry air at $1 \mathrm{~atm}$ and $\left.15^{\circ} \mathrm{C}\right)$, A is a rotor swept area in $\mathrm{m}^{2}$ and $\mathrm{V}$ is the mean value of the wind speed $(\mathrm{m} / \mathrm{s})$.

The power density of the wind $\mathrm{E}$ is

$$
\begin{aligned}
& \text { given as } \mathrm{E}={ }^{1} /{ }_{2} \rho \mathrm{V}^{3} \\
& \text { where }^{\rho}=0.464 \frac{P}{T}
\end{aligned}
$$


From equation $4 \mathrm{P}=$ pressure $(\mathrm{mmHg})$ and $\mathrm{T}=$ temperature in kelvin. Also from equation 4 and 5 , it can be seen that the power density varies directly with the air density. Since the density varies directly with the air atmospheric pressure and inversely with the air temperature. At sea level with a mean temperature of $30^{\circ} \mathrm{C}$, density of air is usually taken as $1.1225 \mathrm{kgm}^{-3}$ (Bakwa \& Jabil, 2002). If the variation of pressure with acceleration due to gravity is neglected then pressure can also vary with altitude as

$$
\frac{d p}{d y}=-\rho g
$$

And since $\rho$ is proportional to $\mathrm{P}$

$$
\frac{\rho}{\rho_{0}}=\frac{P}{P_{0}}
$$

where $P_{0}$ and $\rho_{\mathrm{o}}$ are known values of pressure and density at sea level equation (7) then becomes

$$
\begin{aligned}
& \frac{d p}{P}=-\mathrm{g} \frac{\rho_{0} d y}{P} \text { or } \mathrm{p}=\rho_{0} e^{-a y} \\
& \mathrm{a}=\frac{\mathrm{g} \rho_{0}}{P_{0}}=1.16^{*} 10^{-4} \mathrm{~m}^{-1} \text { at } 27^{\circ} \mathrm{C}
\end{aligned}
$$

Therefore in an ideal, the corrected monthly air density $\rho\left(\mathrm{kg} / \mathrm{m}^{3}\right)$ is expressed as

$$
\rho=\frac{\left(0.464 P_{0} e^{-a y}\right)}{T}
$$

Where $\mathrm{P}$ is in $\mathrm{mmHg}$ and $\mathrm{T}$ is temperature in ${ }^{\mathrm{O}} \mathrm{C}$

Using equation 8 the mean air density for Katsina is $1.18 \mathrm{kgm}^{-3}$ at $50 \mathrm{~m}$ when $\mathrm{T}=30^{\circ} \mathrm{C}$ under optimum conditions the maximum power that can be extracted from the wind is given by

$$
\mathrm{E}_{\max }=\left(\frac{0.593}{2}\right) \rho \mathrm{v}^{3}
$$

The wind energy for a desired duration was calculated using

$$
\mathrm{E}=0.593 * 1 / 2 \rho \mathrm{A}\left[\mathrm{V}^{3} \mathrm{~T}\right]
$$

where V3 is the calculated cube of mean wind speed, A is the rotor swept area, and $\mathrm{T}$ is the desired time.

To adequately evaluate the wind energy potential it is essential to drive the expected probability distribution of the site wind speed. To be able to do this several equations have been propose in literature but in this study we choose to adopt to weibull function which gives an accurate match with experimental data (Ahmed, 2010). Weibull distribution function is characterized by two parameters; the dimensionless shape parameter k; and the scale parameter $\mathrm{c}$ which has a unit of similar to wind speed (m/s) (Mahyoub \& Ahmed, 2012). The general form of weibull probability density function (Celik, 2004) is given by:

$$
\mathrm{P}(\mathrm{V})=(\mathrm{k} / \mathrm{c})(\mathrm{v} / \mathrm{c})^{\mathrm{k}-1} \exp \left[-(\mathrm{v} / \mathrm{c})^{\mathrm{k}}\right]
$$

Where $\mathrm{P}(\mathrm{V})$ is the probability of observing wind speed $\mathrm{v}, \mathrm{k}$ is dimensionless weibull parameter, and $\mathrm{c}$ is the weibull scale parameter.

The higher the value of $\mathrm{k}$, the shaper the curve and the lower the value of $\mathrm{k}$, the flatter and evenly distributed wind speed curves.

$\mathrm{k}$ and c were given by (Justus \& Mikhail, 1976) as follows

$$
\begin{aligned}
& \mathrm{k}=0.83 \mathrm{~V}^{1 / 2} \\
& \mathrm{c}=\mathrm{V} / \Gamma\left(1+\mathrm{k}^{-1}\right)
\end{aligned}
$$

where $\mathrm{V}$ is the mean wind speed and $\Gamma$ is the gamma function

Lysen (1983) used the following approximation to find $c$,

$$
\mathrm{C} / \mathrm{V}=(0.568+0.433 / \mathrm{k})^{-1 / \mathrm{k}}
$$




\section{Result and Discussion}

In this study wind speed data for the 6years period (2008) of the study location was use analyzed, the calculations were made and weibull distribution were obtained as well as monthly power available from the wind power extracted. The results of the analysis can be seen as follows.

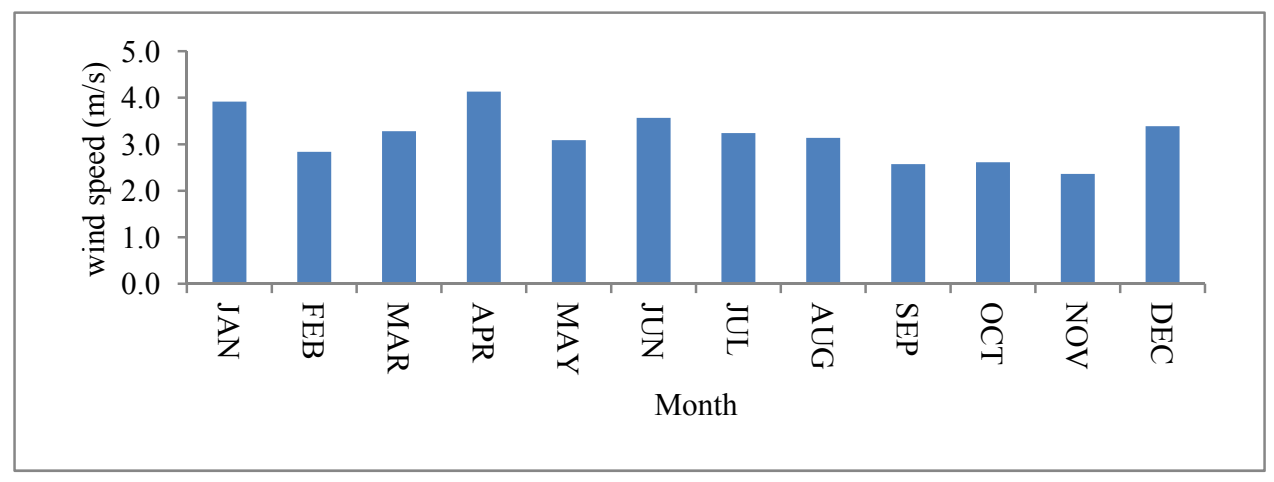

Figure 1. Monthly mean wind speed of Katsina from 2008-2011

From Figure 1, it is obvious that the highest wind speed value occurs in April which corresponds to summer period in katsina. During this period, the maximum temperature records of region fall between $35-36^{\circ} \mathrm{C}$ on average every year at the ground level and decreases with altitude. The decrease in temperature with altitude causes thermal convection so that some of the momentum of the upper air which is moving at a higher velocity is transmitted to the rotor. This causes a speedy rotation and resulted to notice higher speed. Therefore our modified expression looks promising considering the fact that it incorporates some climatological variables. Also from Figure1 it can be seen that, the peak period of wind speed in Katsina occurs between the months of March to August except at may where there is slight decrease in the speed of wind. December and January (harmattan period) also indicate high wind speed values. Table 1 summarizes the monthly wind speed at 10 and $50 \mathrm{~m}$ altitude.

Table 1. Calculated monthly mean wind speed $(\mathrm{m} / \mathrm{s})$ at 10 and $50 \mathrm{~m}$ height above the ground level in Katsina wind site

\begin{tabular}{|c|c|c|c|c|c|c|c|c|c|c|c|c|c|}
\hline \multicolumn{14}{|c|}{ Month } \\
\hline \multicolumn{14}{|c|}{ Annual mean } \\
\hline & January & February & March & April & May & June & July & August & September & October & November & December & \\
\hline $\mathrm{V}_{10}$ & 3.9 & 2.8 & 3.3 & 4.1 & 3.1 & 3.6 & 3.2 & 3.1 & 2.6 & 2.6 & 2.4 & 3.4 & 3.2 \\
\hline $\mathrm{V}_{50}$ & 5.4 & 3.9 & 4.5 & 5.7 & 4.3 & 4.9 & 4.5 & 4.3 & 3.5 & 3.6 & 3.3 & 4.7 & 4.4 \\
\hline
\end{tabular}

It can be seen from Table 1 that, the monthly mean wind speed at extrapolated height $(50 \mathrm{~m})$ varies between $3.3-5.7 \mathrm{~m} / \mathrm{s}$ with a yearly average of $4.4 \mathrm{~m} / \mathrm{s}$ this is in accordance with the wind speed of $4.5 \mathrm{~m} / \mathrm{s}$ obtained by Bakwa \& Jabil (2002) during potential analysis of wind in Jos, Nigeria. Therefore Katsina can be describe as one of the highest wind place in Nigeria compared also with Sokoto and Guru with their mean wind speed of $4.5 \mathrm{~m} / \mathrm{s}$ and $4.3 \mathrm{~m} / \mathrm{s}$ (Ojosu \& Salawu, 1990) respectively. This statement is in line with the findings of Maxwell \& Crokmak (1984) that, sites with mean wind speeds between $3 \mathrm{~m} / \mathrm{s}$ to $4 \mathrm{~m} / \mathrm{s}$ have a good potential for wind power. This indicates that Katsina is a very good site for installing wind mills. Monthly wind speed distribution for the period of study is displayed in Figure 2. 


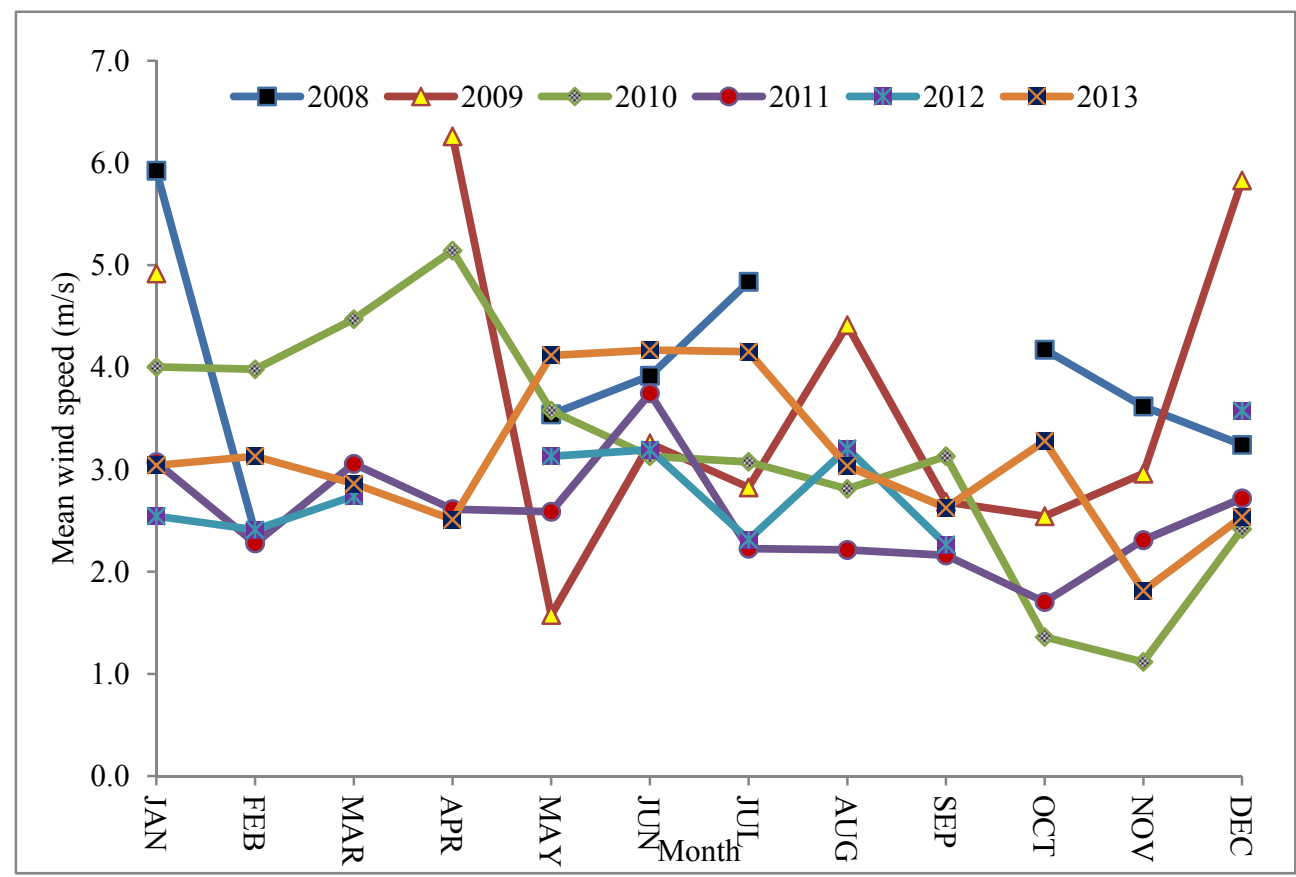

Figure 2. The monthly distribution of wind speed from 2008-2013

As can be seen from Figure 2, the mean wind speed was distributed more closely to the mean values from May to September. While beginning and end of the each year shows large variations. This is probably due to influences of harmattan season. It also shows that on average 2008 and 2009 shows highest wind speed record. Table 2 shows the monthly Weibull parameters $\mathrm{k}$ and $\mathrm{c}$.

Table 2. Monthly 6 years shape parameter, $\mathrm{k}$, and scale parameter, $\mathrm{c}$, at $10 \mathrm{~m}$

\begin{tabular}{ccc}
\hline Month & $\mathrm{k}$ & $\mathrm{C}(\mathrm{m} / \mathrm{s})$ \\
\hline January & 1.6 & 3.9 \\
February & 1.4 & 2.8 \\
March & 1.5 & 3.3 \\
April & 1.7 & 4.1 \\
May & 1.5 & 3.1 \\
June & 1.6 & 3.6 \\
July & 1.5 & 3.2 \\
August & 1.5 & 3.1 \\
September & 1.3 & 2.6 \\
October & 1.3 & 2.6 \\
November & 1.3 & 2.4 \\
December & 1.5 & 3.4 \\
Annual mean & 1.5 & 3.2 \\
\hline
\end{tabular}

The calculated Weibull parameters for the available data presented in Table 2 shows that these parameters are distinctive for different months within the study period (2008-2013). The parameter $\mathrm{k}$ shows highest value of 1.7 in April and lowest of 1.3 in September to November while c shows highest value of 4.1 also in April with lowest value of $2.4 \mathrm{~m} / \mathrm{s}$ in November. Based on this result it shows that in Katsina state wind speed is most uniform in April while lease uniform in September. This also corresponds to the highest wind speed value found in April (Figure 1 and Table 1). The monthly cube of mean wind speed at $10 \mathrm{~m}$ and $50 \mathrm{~m}$ altitude is presented in Table 3 . 
Table 3. Cube of monthly wind speed (m/s) for Katsina (2008-2013)

\begin{tabular}{|c|c|c|c|c|c|c|c|c|c|c|c|c|c|}
\hline \multicolumn{14}{|c|}{ Month } \\
\hline & January & February & March & April & May & June & July & August & September & October & November & December & \\
\hline $\mathrm{V}^{3}{ }_{10}$ & 77.4 & 26.6 & 40.5 & 103.7 & 35.3 & 47.1 & 43.3 & 36 & 17.9 & 36.4 & 18.6 & 54.7 & 43.9 \\
\hline $\mathrm{V}^{3}{ }_{50}$ & 203.3 & 69.9 & 106.2 & 272.3 & 92.7 & 123.8 & 113.7 & 94.4 & 47.1 & 69.2 & 48.8 & 143.6 & 115.4 \\
\hline
\end{tabular}

The cube mean wind speed displayed in Table 3 aims at calculating the wind power available, mean wind power extractable and monthly mean wind energy. The result of this estimation is shown in Table 4.

Table 4. Monthly Mean power available, Extractable Power density and Monthly Mean Wind Energy

\begin{tabular}{cccccc}
\hline Month & $\begin{array}{c}\text { Monthly } \\
\text { Averarage } \\
\mathrm{V}_{50}(\mathrm{~m} / \mathrm{s})\end{array}$ & $\begin{array}{c}\text { Monthly } \\
\text { Averarage } \\
\mathrm{V}^{3}{ }_{50}(\mathrm{~m} / \mathrm{s})\end{array}$ & $\begin{array}{c}\text { Power density } \\
\text { available }\left(\mathrm{W} / \mathrm{m}^{2}\right)\end{array}$ & $\begin{array}{c}\text { Power density } \\
\text { extractable } \\
\left(\mathrm{W} / \mathrm{m}^{2}\right)\end{array}$ & $\begin{array}{c}\text { Monthly } \\
\text { mean wind } \\
\text { energy } \\
\text { (Kwh/year }\end{array}$ \\
\hline January & 5.4 & 203.3 & 119.9 & 71.1 & 52.9 \\
February & 3.9 & 69.9 & 41.3 & 24.5 & 16.6 \\
March & 4.4 & 106.2 & 62.7 & 37.2 & 27.7 \\
April & 5.7 & 272.3 & 160.6 & 95.3 & 68.6 \\
May & 4.3 & 92.7 & 54.7 & 32.4 & 24.1 \\
June & 4.9 & 123.8 & 73.0 & 43.3 & 31.2 \\
July & 4.5 & 113.7 & 67.1 & 39.8 & 29.6 \\
August & 4.3 & 94.4 & 55.7 & 33.0 & 24.6 \\
September & 3.5 & 47.1 & 27.8 & 16.5 & 11.9 \\
October & 3.6 & 69.2 & 40.8 & 24.2 & 12.0 \\
November & 3.3 & 48.8 & 28.8 & 17.1 & 37.4 \\
December & 4.7 & 143.6 & 84.7 & 50.3 & 29.6 \\
Annual mean & 4.4 & 115.4 & 68.1 & 40.4 & \\
\hline
\end{tabular}

From Table 4 the monthly mean power density available at $50 \mathrm{~m}$ height is found to vary between $27.8-160.8$ $\mathrm{Wm}^{-2}$ with an overall average of $68.1 \mathrm{Wm}^{-2}$ per year over 6years. The mean power density extractable at the same height $(50 \mathrm{~m})$ varies from $16.5-95.3 \mathrm{Wm}^{-2}$ with a yearly mean of $40.4 \mathrm{Wm}^{-2}$. The monthly mean wind energy ranges from 11.9-68.6 Kwh/year with total annual wind energy of $29.6 \mathrm{Kwh} / \mathrm{year}$. This value is greater than the 24.9 Kwh/year given by Bakwa \& Jabil (2002) at Jos, Plateau state Nigeria. the increased can be associated with the incorporation of the height variation factor in our modified empirical relation for calculating density of air with height as well as choosing the exponent in calculating the extrapolated height being plateau a hilly region and Katsina state a forested area (Equation 8 and 1). It is obvious that, the pattern of annual mean wind speed (Figure 3) at both 10 and $50 \mathrm{~m}$ for the year has not change.

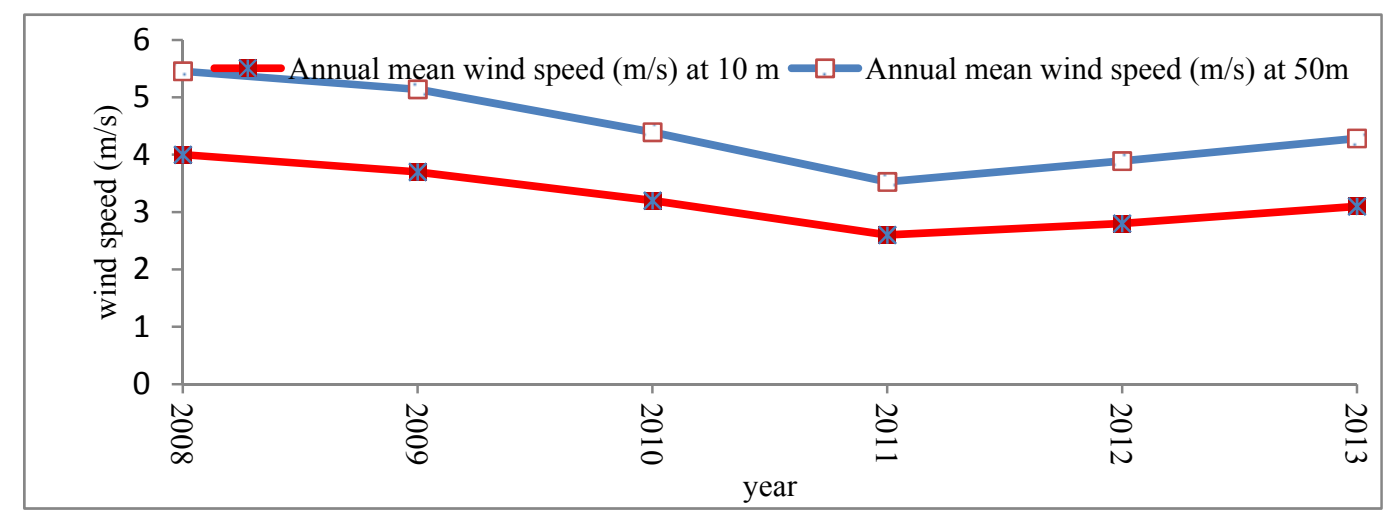

Figure 4. Trend of annual mean wind speed at 10 and $50 \mathrm{~m}$ altitude 
The similarity in the wind speed pattern in Figure 3, is an indication that Katsina state can be conveniently used for construction of wind mills. And that if constructed it can be utilized for electric power generation for pumping water from a deep wells or bore holes for irrigation, drinking, livestock production and many more for a longer period. The essence of comparing this result with the previous results is to ascertain the accuracy of the presented result but it is left open for further work to adjudge the findings. Especially the use of long term historical data this will give more clue on the wind condition of the area before the actual construction of wind mills as this paper present only preliminary assessment using monthly average data for six years.

\section{Conclusion}

In this study the wind speed data for katsina state were statistically analyzed using a 6 years (2008-2013) period data obtained from NOAA-NCDC. The power density available in the wind and that which can be extracted were estimated in addition to monthly mean energy per year. The result of the estimated weibull parameters shows that, the monthly value of $\mathrm{k}$ varies between 1.3-1.7 and $\mathrm{c}$ varies from 2.4-4.1 m/s respectively. The annual mean wind speed at 50 meter altitude in this site is found in the range of $3.5-5.5 \mathrm{~m} / \mathrm{s}$. The result also established that the month of April shows the highest monthly mean power density of $160.6 \mathrm{~W} / \mathrm{m}^{2}$ while the month of September shows the lowest monthly mean power density. Analysis of monthly and annual mean wind energy also shows that an average of $29.6 \mathrm{Kwh} / \mathrm{year}$ of energy can be produced for each month of a year while a total of $355.2 \mathrm{Kwh} /$ year can be produce annually (12 month period). And this has led to our conclusion that Katsina state has good wind potential. Therefore the energy in the wind can be effectively harnessed and utilized for some useful work like electric generation, pumping of water for drinking etc. This can supplement the use of diesel for irrigation and above mentioned activities. The attention of Katsina state government is drawn to fact that the state has an abundant potential for wind power and therefore should take steps to initiate wind related programs that could benefit her rural populace.

\section{Acknowledgement}

The visibility and meteorology data were provided by the NOAA/NESDIS/NCDC, the authors therefore wish to thank Stuart Hinson a Meteorologist, NOAA-NCDC for providing the data.

\section{References}

Ahmed, S. A. (2010). Wind energy as a potential generation source at Ras Benas. Egypt journal Renewable and Sustainable Energy Reviews, 2, 2167-2173. http://dx.doi.org/10.1016/j.rser.2010.03.006

Ajayi, O. O. (2009). Assessment of utilization of wind energy resources in Nigeria. Energy Policy, 37, 750-753. http://dx.doi.org/10.1016/j.enpol.2008.10.020

Ajayi, O.O., Fagbenle, R. O., \& Katende, J. (2011). Assessment of Wind Power Potential and Wind Electricity Generation Using WECS of Two Sites in South West, Nigeria. International Journal of Energy ScienceIJES, l(20), 78-92.

Asiegbu, A. D., \& Iwuoha, G. S. (2007). Studies of wind resources in Umudike, South East Nigeria - An assessment of economic viability. Journal of Engineering and Applied sciences, 2(10), 1539-1541.

Bakwa, D. D., \& Jabil, Y. Y. (2002). The assesnent of wind power potential of Jos. Nigerian journal of Environmental sciences, 6(1), 9-17.

ECN-UNDP. (2005). Renewable energy master plan, final draft report. Retrieved June 17, 2007, from http://www.iceednigeria.org/REMP\%20Final\%20Report.pdf

Esterhuyse, J. E. (1985). Harnessing wind using axial flow turbine CSIR Report Pretoria.

Fadare, D. A. (2010). The application of artificial neural networks to mapping of wind speed profile for energy application in Nigeria. Applied Energy, 87, 934 - 942.

Fadare, D. A. A. (2008). Statistical analysis of wind energy potential in Ibadan, Nigeria, based on weibull distribution function. the pacific journal of science and technology, 9(1), 110-119.

Fagbenle, R. O., \& Karayiannis, T. G. (1994). On the wind energy resources of Nigeria. International Journal of Energy research, 18(5), 493-508.

Fagbenle, R. O., Katende, J., Ajayi, O. O., \& Okeniyi, J. O. (2011). Assessment of wind energy potential of two sites in North - East, Nigeria. Renewable Energy, 36, 1277-1283.

Hennessey, J. R. J. P. (1977). Some aspects of wind power statistics. Journal of Applied Meteorology, 16(2), 119-128. 
Justus, C. G., \& Mikhail, A. (1976). Height variation of wind speed and wind distributions statistics. Geophysical Research Letters, 3(5), 261-264.

Katsoulis, B. D. (1992). A survey on the assessments of wind energy in Greece. Theor Appl. Climatol., 47, 51-63.

Lysen, E. H. (1983). Introduction to Wind Energy. SWD Publication SWD 82-1, the Netherlands.Annual Energy.

Mahayoub, H, A., \& Ahmed, A. (2012). Monthly and seasonal investigation of wind characteristics and potential in Al-Mokha, Yemen. Journal of Energy and Power Engineering, 4, 125-131. http://dx.doi.org/10.4236/epe.2012.43017

Manwell, A. A. A., \& Crokmak, D. E. (1984). Understanding wind energy Vita Arlington.Virginia.

Naci, A. (2003). Energy output estimation for small-scale wind power generators using Weibull-representative wind data. Journal of Wind Engineering and Industrial Aerodynamics, 91, 693-707. http://dx.doi.org/10.1016/S0167-6105(02)00471-3

Nickovic, S., \& Petkovic. (1987). Interpretation of numerical weather forecast. Proc. Congress elem. Atm Dias, 3, 114-121.

Ogbonnaya, I. O., Chikuni, E., \& Govender, P. (2009). Prospect of wind energy in Nigeria. Retrieved July 16, 2009, from http://active.cput.ac.za/energy/web/due/papers/2007/023O_Okoro.pdf

Ojosu, J. O., \& Salawo, R. I. (1990). Wind energy development in Nigeria. Nigerian journal of solar energy, 9 , 19-27.

Review 2000 (2001). Washington D. C.: Energy Information Administration, DOE/EIA-0384 (2000).

Sambo, A. S., \& Taylor, P. F. U. (1990). Renewable energy source for rural electrification. Nigerian Journal of renewable energy, 1, 18-33.

Sirisena, U. A. I., Alfa, A. B., \& Bakwa, D. D. (1991). Assessment of wind power potential at Heipang jos using climatological data. Nigerian journal of solar energy, 10, 44-53.

\section{Copyrights}

Copyright for this article is retained by the author(s), with first publication rights granted to the journal.

This is an open-access article distributed under the terms and conditions of the Creative Commons Attribution license (http://creativecommons.org/licenses/by/3.0/). 